\title{
Anesthesia by sprinkling method in the gills of tambaqui Colossoma macropomum does not influence intensity and morphology of monogeneans
}

\author{
C. L. Boijink, , P. O. Maciel ${ }^{b}$, M. Tavares-Dias ${ }^{c}$, M. K. P. Iwashita, , M. S. Morais ${ }^{d}$, \\ D. M. V. Hide , N. C. Souzaf, M. V.S. Couto , J. O. Meneses ${ }^{e}$, F. S. Cunha and R. Y. Fujimoto ${ }^{g} *$ \\ ${ }^{a}$ Embrapa Amazonia Ocidental, Rod. AM 010, Km 29, CEP 69010-970, Manaus, AM, Brazil \\ ${ }^{b}$ Embrapa Pesca e Aquicultura, Quadra 104 Sul, Avenida LO 1, 34, Conjunto 4, CEP 77020-020, Palmas TO, Brazil \\ ${ }^{\circ}$ Embrapa Amapá, Rod. Juscelino Kubitscheck, 2600, Km 5, CP 10, CEP 68906-970, Macapá, AP, Brazil \\ dUninorte Manaus, Av. Leonardo Malcher, 853, Centro, CEP 69010-060, Manaus, AM, Brazil \\ 'Universidade Tiradentes - UNIT, Av. Murilo Dantas, 300, Farolândia, CEP 49032-490, Aracaju, SE, Brazil \\ fUniversidade Federal do Pará - UFPA, Rua Augusto Corrêa, Guamá, CP 479, CEP 66075-110, Belém, PA, Brazil \\ gEmbrapa Tabuleiros Costeiros, Avenida Beira Mar, 3250, CEP 49025-040, Aracaju, SE, Brazil \\ *e-mail: rodrigo.fujimoto@embrapa.br
}

Received: September 25, 2015 - Accepted: March 8, 2016 - Distributed: May 31, 2017

(With 3 figures)

\begin{abstract}
The present study evaluates the influence of anesthesia on the parasitic fauna of monogenea fish parasites, as its intensity and viability. Two experiments were conducted: Evaluation of an anesthetic method by sprinkling eugenol directly on gills and evaluation of monogenea motility and viability; Comparison of immersion and directly sprinkling on the gills with benzocaine and eugenol followed by evaluation on parasite intensity. The results suggest that the anesthetic sprinkling didn't interfere in the parasite motility, morphology and body surface integrity analyzed by fluorescence method. The monogenean intensity in the gills was lower in fish anesthetized by immersion method compared to the sprinkling method and the control group. This method of anesthesia can be used in parasitological studies.
\end{abstract}

Keywords: parasitology, animal welfare, humane slaughter, histopathology.

\section{Anestesia por meio de aspersão nas brânquias de tambaqui Colossoma maropomum não influencia a intensidade e a morfologia de monogeneas}

\section{Resumo}

O presente estudo avalia a influência da anestesia sobre a fauna parasitária de monogeneas em peixes, sua intensidade e sua viabilidade. Dois experimentos foram realizados: Avaliação de um método anestésico por aspersão eugenol diretamente nas brânquias e avaliação da motilidade das monogeneas e sua viabilidade; e Comparação entre imersão e aspersão diretamente nas brânquias com benzocaína e eugenol, seguido de avaliação sobre a intensidade parasitária. Os resultados sugerem que a aspersão do anestésico não interferiu na motilidade, morfologia, superfície corporal e integridade do parasita, analisadas pelo método de fluorescência. A intensidade de monogenéticos nas brânquias foi menor nos peixes anestesiados pelo método de imersão em comparação com o método de aspersão e o grupo controle. O método de anestesia por aspersão nas brânquias pode ser utilizado em estudos parasitológicos.

Palavras-chave: parasitologia, bem-estar animal, o abate humanitário, histopatologia.

\section{Introduction}

The use of anesthesia in fish prior to euthanasia for parasitological studies is a challenged due to changes in the ectoparasites fauna and its morphology. In addition, ictioparasitologists are questioned by the Animal Research Ethics Committees (AREC) by not adopting prior anesthesia to perform euthanasia on animals in order to minimize the pain and animal suffering.

According to the Brazilian Council for Animal Experiments (BCAE), fish euthanasia should be carried out in two stages, (1) anesthesia to cause total loss of 
equilibrium followed by a physical method such as (2) concussion (stunning), spinal cord section or chemical that promotes brain death (Brasil, 2013).

Anesthetics are used in aquaculture in production practices, teaching and research to reduce stress in fish during management practices, to decrease stimuli reaction over collection of biological material and even to promote stunning prior to euthanasia (Ross and Ross, 1999; Roubach et al., 2005; Inoue et al., 2005; Brasil, 2013). In Brazil the anesthetics commonly used in aquaculture are benzocaine (benzocaine hydrochloride) and eugenol (clove oil). Anesthetics and physiological effects after administration by immersion of these two products have been tested in tambaqui Colossoma macropomum (Gomes et al., 2001; Roubach et al., 2005), the most cultivated native fish (IBGE, 2013).

Several studies in disease control, diagnostics and treatments have been conducted to enhance understanding on this specie to increase productivity (Pinheiro et al., 2015; Boijink et al., 2015). Also, it has recently been demonstrated anthelmintic activity of eugenol against gill parasites in tambaqui, which indicates the possibility of anesthetic interference in studies with ectoparasites (Boijink et al., 2015).

The overall aim of this study was to evaluate the interference of the anesthetics methods of immersion and sprinkling with benzocaine and eugenol in tambaqui gill parasites.

\section{Material and Methods}

\subsection{Animals}

Tambaqui juveniles were kept for two weeks in $1000 \mathrm{~L}$ tank with constant aeration and water renovation prior to the experiments. They were fed twice daily extruded feed $(34 \% \mathrm{CP})$ to satiation. Parasitic analyzes were performed to confirm the presence of monogeneans in the gills.

\subsection{Experiment 1: anesthetic sprinkling method, viability and parasite identification}

Ten fish $(269.0 \pm 49.5 \mathrm{~g}, 22.75 \pm 2.75 \mathrm{~cm})$ were individually anesthetized by sprinkling $1 \mathrm{~mL}$ of eugenol solution on the gills, left side. This solution was prepared with $1 \mathrm{~mL}$ of eugenol diluted in $9 \mathrm{~mL}$ of alcohol and in $440 \mathrm{~mL}$ of water (adapted from Honczaryk and Inoue, 2009). Anesthetic induction time was registered, using a stopwatch. Behavioural changes in each fish were observed according to Keene et al. (1998). Clinical signs as lack of response to external stimuli and total loss of muscle tone were used to characterize the anaesthetic stage IV (deep anaesthesia) (adapted from Hikasa et al., 1986).

The residual liquid from the sprinkling was collected and analyzed for parasites presence. After achieving the anesthetic stage V (Hikasa et al., 1986), the fish were euthanized through medullar section and gills were removed and separated into Petri dishes. It was considered the gills on the left side with the anesthetic (LSWE), and the gills of the right side, without anesthetic (RSWOE) the control group. This experimental design was applied by Turgut et al. (2006), Tripathi et al. (2010), Tombi et al. (2014) and Gilbert and Avenant-Oldewage (2016), and showed similar parasites count between left and right sides of gills.

A gill fragment from each side was fixed in $10 \%$ buffered formalin for histological analysis, according Behmer et al. (1976).

After gill collection, 20 monogeneans parasites on either side of the gills were separated for evaluation of motility and viability by fluorescence method adapted from Maria et al. (2010). Each parasite was allocated in a well of a Kline plate with $200 \mathrm{uL}$ of distilled water and $2.5 \mathrm{uL}$ of SYBR-14 fluorochromes (green) and 2.5 uL propidium iodide (red), final concentrations of $250 \mathrm{nM}$ SYBR-14 and $30 \mu \mathrm{M}$ propidium iodide. This technique allows the view of viable parasites in green, and the dead or damaged ones, in red color. As negative control, live monogeneans without eugenol exposure were used and as positive control it was used monogeneans killed by $2.5 \%$ glacial acetic acid.

The identified parasites were selected by staining with Gomori trichrome and Hoyers solution method (Eiras et al., 2006; Thatcher, 2006). The gills, from the left and right sides were stored separately in 5\% formaldehyde (Eiras et al., 2006) until counting in a stereomicroscope to calculate the total intensity.

\subsection{Experiment 2: comparison between immersion and sprinkling method on parasites load}

Fifty fish $(163.24 \pm 34.74 \mathrm{~g} ; 20.02 \pm 2.52 \mathrm{~cm})$ were distributed randomly (10 fish/treatment): (1) control, without anesthetics, animals were sampled directly in the tank and euthanatized by medullar section; (2) bath immersion with benzocaine (100 mg/L); (3) bath immersion with eugenol $(50 \mathrm{mg} / \mathrm{L})$; (4) benzocaine sprinkling $(100 \mathrm{mg} / \mathrm{L})$ directly on the gills; and (5) eugenol sprinkling (50 mg/L) directly on the gills.

A stock solution was prepared from each anesthetic. Clove oil was obtained commercially (Vetec ${ }^{\circledR}$, eugenol $1 \mathrm{~g} / \mathrm{mL}$ ) and diluted 1:20 (v/v) in 95\% ethanol to obtain $50 \mathrm{mg} / \mathrm{mL}$ (Honczaryk and Inoue, 2009). The benzocaine was diluted, $10 \mathrm{~g}$ in $100 \mathrm{~mL}$ of ethanol (1:10) and then diluted in $1 \mathrm{~L}$ distilled water, 1:100 (v/v). Aliquots of the stock solutions were used to achieve the doses tested.

In the immersion baths, the anesthetic stock solutions were diluted in a $20 \mathrm{~L}$ container, where the fish were kept for 180 seconds until equilibrium loss, identified as stage 4 of deep anesthesia (Ross and Ross, 1999). In the sprinkling method, the anesthetic solutions were stored in polyethylene sprinklers, and approximately $10 \mathrm{~mL}$ of the solution were sprinkled on the gills on each side. After 150 seconds the fish were desensitized.

\subsection{Statistics analysis}

Compared $\mathrm{T}$ test were used in experiment 1 for monogenean counting, left and right sides. One-way ANOVA and Tukey test were used to analyze experiment 2 data. Descriptive statistics were used in the remaining data. 


\section{Results}

In experiment 1 , the fish reached deep anesthesia in 40 seconds, characterized by absence of stimuli response by touch and opercular movement. There was no difference in the intensity of monogeneans $(173 \pm 120)$ among the side sprinkled with eugenol and the control group $(158 \pm 120)$ $(p=0.47)$ (Figure 1). Residual liquid was collected and analyzed from two samples and no parasites were found after anesthetic application.

The use of eugenol did not affect parasites morphology, enabling its identification as Anacanthorus spathulatus and Notozothecium janauachensis. The parasites were viable and showed normal motility, according to the direct analysis in stereomicroscope. In fluorescence analysis, no integrity changes on the body surface of the parasites were observed.

It was observed that sprinkling eugenol in the studied concentration directly on gills promoted changes on its morphology, such as lamellar vascular axis vasodilatation, interstitial edema and lamella epithelial lifting (Figure 2).

In experiment 2 , the average intensity of monogeneans in the gill of fish anesthetized by immersion was lower compared to the other groups (Figure 3). Loss of $44.4 \%$ and $42.5 \%$ in parasite intensity in the gills of fish exposed to immersion method with benzocaine as with eugenol respectively.

\section{Discussion}

Anesthesia by gill sprinkling method with benzocaine and eugenol promoted deep anesthesia and preserved the number of parasites in the fish's gills. The deep anesthesia was achieved in 40 seconds in experiment 1 , and 150 seconds in experiment 2, after complete stop of opercular movement and followed by the behavioral observations of Honczaryk and Inoue (2009).

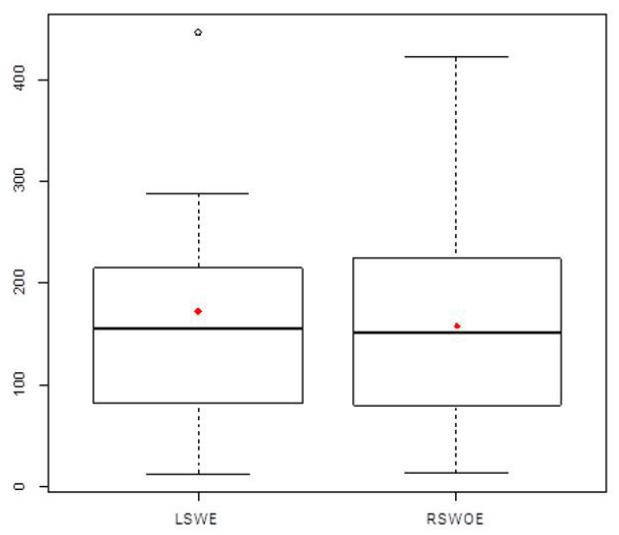

Figure 1. Monogenean intensity in the gills left side with eugenol (LSWE), and gills right side, without eugenol (RSWOE), of tambaqui juvenile Colossoma macropomum anesthetized by sprinkling method.
In most of anesthetic procedures in fish, the solutions are administered in the water by immersion baths (Stoskopf, 1993). Immersion baths with benzocaine at doses of $100 \mathrm{mg} / \mathrm{L}$ for 2.71 minutes (Gomes et al., 2001) and eugenol $65 \mathrm{mg} / \mathrm{L}$ for 3.77 minutes (Roubach et al., 2005) have

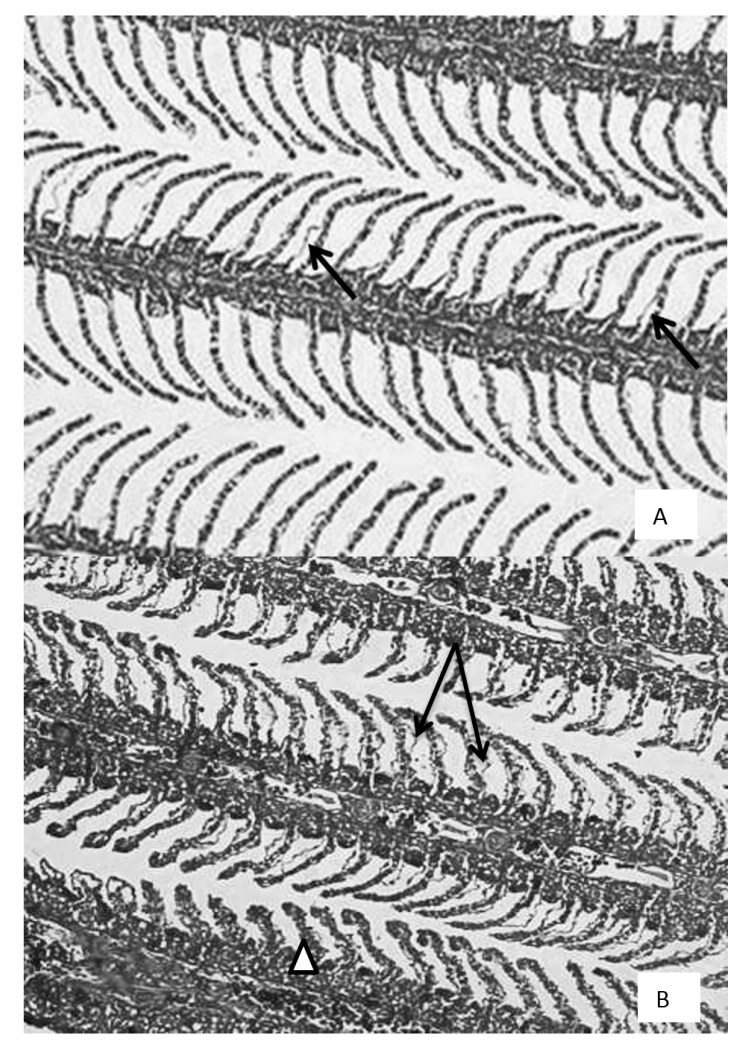

Figure 2. Tambaqui juvenile Colossoma macropomum gills from the control group (A), without anesthetic solution exposure, showing regular characteristics, with occasional edema $(\rightarrow)$; and gills exposed to eugenol (B), showing lamellar vascular axis vasodilatation (triangle), edema spots and epithelial lifting $(\rightarrow)$ and 100x, HE.

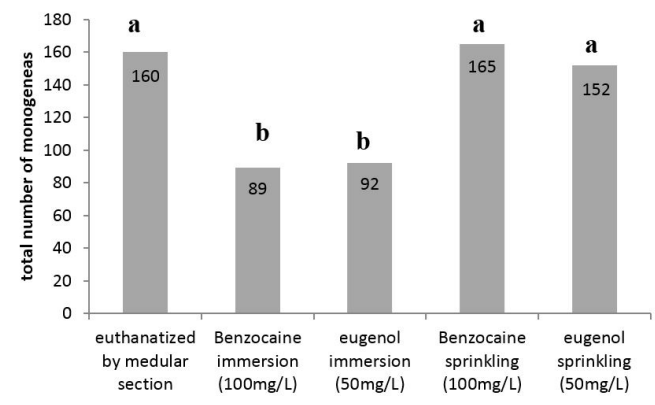

Figure 3. Average monogeneans intensity in the gills of tambaqui juvenile Colossoma macropomum exposed to different methods of desensitization with benzocaine and eugenol anesthetics. Different letter above the bars represent statistical difference by Tukey test $(\mathrm{p}<0.05)$. 
been previously validated for tambaqui anesthesia. In this procedure the internalization of the active substance into the animal's circulatory system is performed through the gills and cutaneous absorption, and then blocking reflex actions (Summerfelt and Smith, 1990).

In present experiments the time of induction of anesthesia was lower compared to immersion method. Sprinkling anesthetics on the gills is based on same technical principle and the method was tested in pirarucu Arapaima gigas and has proven to be viable at concentrations of 30 and $60 \mathrm{mg} / \mathrm{L}$ of eugenol (Honczaryk and Inoue, 2009). Probably, the direct contact of the anesthetic with the gills provided satisfactory absorption and reduction on times of induction.

The difference among times of induction in the two experiments was due to the stock solution concentration, because in experiment 2 the stock solution was more diluted to avoid gill alterations, as observed in experiment 1 .

In Brazil legislation of anesthetics in fish is scarce, the National Council for Animal Experiments Control (Brasil, 2013) mainly indicates MS-222, benzocaine and eugenol for anesthesia in prior to euthanasia. However, the immersion method is not recommended to study of the intensity and abundance of parasites in fish gills (Boijink et al., 2015). Nevertheless, according to the results, sprinkling eugenol on the gills does not promote morphological and viability changes in the parasites. The fluorescence technique is widely used to assess sperm viability (Maria et al., 2010; Arruda et al., 2011) and protozoa studies (Davies and Stewart, 2000; Zhang et al., 2013; Song et al., 2015). Methods employing fluorescent dyes extend the possibility of a detailed structural integrity analysis of the observed organisms (Arruda et al., 2011).

Regarding histological aspects, it is known that due to stressful conditions the gill tissue can suffer adjustments in three ways: change the water flow through the gills; change the blood flow through the gills; or change the gill morphology to adapt to the new condition (Nilsson, 2007).

Histologically there was edema and vasodilatation in gills exposed to eugenol sprinkling. These changes characterize an inflammatory response and represent a typical response to xenobiotics exposure (Nascimento et al., 2012). Lamellar epithelium detachment associated with edema is the mostly common alteration found in response to stressors. According to Movahedinia et al. (2012) these alterations aim to increase the diffusion distance between the pollutant and blood. Similar histological changes were also observed in gills of other fish species, as shown in carp Cyprinus carpio (Velisek et al., 2005) and European catfish Silurus glanis (Velisek et al., 2006), considered momentary due to the contact with the anesthetic.

\section{Conclusion}

The gill sprinkling method of anesthesia using benzocaine or eugenol were effective methods for tambaqui anesthesia in the tested concentrations. It is feasible to use the same dose prior to fish euthanasia, associated with a physical method, in accordance with the precepts of animal ethics.
Furthermore, these anesthetic methods have not compromised the parasitological studies of monogeneans in the gills, preserving their viability and integrity.

\section{References}

ARRUDA, R.P., CELEGHINI, E.C.C., ALONSO, M.A., CARVALHO, H.F., OLIVEIRA, L.Z., NASCIMENTO, J., SILVA, D.F., AFFONSO, F.J., LEMES, K.M. and JAIMES, J.D., 2011. Methods of the assessment of morphology and function of sperm: actual moment and future challenges. Revista Brasileira de Reprodução Animal, vol. 35, no. 2, pp. 145-151.

BEHMER, O.A., TOLOSA, E.M.C., and FREITAS NETO, A.G., eds. 1976. Manual de técnicas para histologia normal e patológica. São Paulo: Edart. 256 p.

BOIJINK, C.L., MIRANDA, W.S.C., CHAGAS, E.C., DAIRIKI, J.K., and INOUE, L.A.K.A., 2015. Anthelmintic activity of eugenol in tambaquis Colossoma macropomum with monogean gill infection. Aquaculture, vol . 438, pp. 138-140.

BRASIL. Ministério da Ciência e Tecnologia. Conselho Nacional de Controle de Experimentação Animal - CONCEA, 2013. Diretrizes da Prática de Eutanásia do Conselho Nacional de Controle de Experimentação Animal - CONCEA. Brasília: SBCAL/COBEA. 54 p.

DAVIES, A., STEWART, B., 2000. Autofluorescence in the oocysts of marine and freshwater fish coccidia. Folia Parasitologica, vol .47, pp. 157-158.

EIRAS, J.C., TAKEMOTO, R.M. and PAVANELLI, G.C., 2006. Métodos de estudo e técnicas laboratoriais em parasitologia de peixes. 2nd ed. Maringá: Universidade Estadual de Maringá. 199 p.

GILBERT, B.M. and AVENANT-OLDEWAGE, A., 2016. Seasonal occurrence and microhabitat specificity of Paradiplozoon ichthyoxanthon Avenant-Oldewage in Avenant- Oldewage et al., 2014 (Monogenea: Diplozoidae) infecting Labeobarbus aeneus (Burchell) (Teleostei: Cyprinidae) from the Vaal Dam, South Africa: water quality and host size as determining factors? Folia Parasitologica, vol. 63, pp. 1-7. PMid:27004521.

GOMES L.C., CHIPPARI-GOMES, A.R., LOPES, N.P., ROUBACH, R., and ARAUJO-LIMA, C.A.R.M., 2001. Efficacy of benzocaine as anesthetic for tambaqui juveniles (Colossoma macropomum). Journal of the World Aquaculture Society, vol. 31, pp. 426-431. http://dx.doi.org/10.1111/j.1749-7345.2001.tb00470.x.

HIKASA, Y., TAKASE, K., OGASAWARA, T. and OGASAWARA, S., 1986. Anesthesia and recovery with tricaine methane-sulfonate, eugenol and thiopental sodium in the carp, Cyprinus carpio. Japanese Journal of Veterinary Science, vol. 48, no. 2, pp. 341351. http://dx.doi.org/10.1292/jvms1939.48.341. PMid:3712895.

HONCZARYK, A. and INOUE, L.A.K.A., 2009. Anestesia do pirarucu por aspersão direta nas brânquias do eugenol em solução aquosa. Ciência Rural, vol. 39, no. 2, pp. 577-579. http://dx.doi. org/10.1590/S0103-84782008005000084.

INOUE, L., AFONSO, L., IWAMA, G.K. and MORAES, G., 2005. Effects of clove oil on stress responses of matrinxa subjected to transport. Acta Amazonica, vol. 35, no. 2, pp. 289-295. http:// dx.doi.org/10.1590/S0044-59672005000200018.

INSTITUTO BRASILEIRO DE GEOGRAFIA E ESTATÍSTICA - IBGE, 2013. Produção da Pecuária Municipal. Rio de Janeiro: IBGE. 108 p. 
KEENE, J. L., NOAKES, D. L. G., MOCCIA, R. D. and SOTO, C. G., 1998. The efficacy of clove oil as an anaesthetic for rainbow trout, Oncorhynchus mykiss (Walbaum). Aquaculture Research, vol. 29 , no. 2, pp. 89-101. http://dx.doi.org/10.1046/j.13652109.1998.00927.x.

MARIA, A.N., AZEVEDO, H.C., SANTOS, J.P., SILVA, C.A. and CARNEIRO, P.C.F., 2010. Semen characterization and sperm structure of the Amazon tambaqui. Journal of Applied Ichthyology, vol. 26, no. 5, pp. 779-783. http://dx.doi.org/10.1111/j.14390426.2010.01542.x.

MOVAHEDINIA, A., ABTAHI, B. and BAHMANI, M., 2012. Gill histopathological lesions of the Sturgeons. Asian Journal of Animal and Veterinary Advances, vol. 7, no. 8, pp. 710-717. http://dx.doi.org/10.3923/ajava.2012.710.717.

NASCIMENTO, A.A., ARAUJO, F.G., GOMES, I.D., MENDES, R.M. and SALES, A., 2012. Fish gills alterations as potential biomarkers of environmental quality in a eutrophized tropical river in south-eastern Brazil. Anatomia, Histologia, Embryologia, vol. 41, no. 3, pp. 209-216. http://dx.doi.org/10.1111/j.14390264.2011.01125.x. PMid:22211803.

NILSSON, G.E., 2007. Gill remodeling in fish - a new fashion or an ancient secret? The Journal of Experimental Biology, vol. 210, no. Pt 14, pp. 2403-2409. http://dx.doi.org/10.1242/jeb.000281. PMid:17601943.

PINHEIRO, D.A., CAVERO, B.A.S., VARGAS, L., BRACCINI, G.L., YOSHIOKA, E.T.O., OLIVEIRA, M.S.B. and TAVARESDIAS, M., 2015. Performance, parasitic infections, hematology and hepatic histology of tambaqui fed on homeopathic product. African Journal of Pharmacy and Pharmacology, vol. 9, no. 4, pp. 82-90. http://dx.doi.org/10.5897/AJPP2014.4194.

ROSS, L.G. and ROSS, B., 1999. Anaesthetic and sedative techniques for aquatic animals. Oxford: Blackwell Science.

ROUBACH, R., GOMES, L.C., FONSECA, F.A.L. and VAL, A.L., 2005. Eugenol as an efficacious anesthetic for tambaqui, Colossoma macropomum (Cuvier). Aquaculture Research, vol. 36, no. 11, pp. 1056-1061. http://dx.doi.org/10.1111/j.13652109.2005.01319.x.

SONG, K., LING, F., HUANG, A., DONG, W., LIU, G., JIANG, C., ZHANG, Q. and WANG, G., 2015. In vivo and in vitro assessment of the effect of antiprotozoal compounds isolated from Psoralea corylifolia against Ichthyophthirius multifilis in fish. International Journal for Parasitology. Drugs and Drug Resistance, vol. 5, no. 2, pp. 58-64. http://dx.doi.org/10.1016/j. ijpddr.2015.04.001. PMid:26042195.

STOSKOPF, M., 1993. Anaesthesia. In: L. BROWN, ed. Aquaculture for veterinarians: fish husbandry and medicine. London: Butterworth-Heinemann, pp.161-168, Pergamon Veterinary Handbook Series.

SUMMERFELT, R.C. and SMITH, L.S., 1990. Anesthesia, surgery, and related techniques. In: C.B. SCHRECK and P. B. MOYLE. Methods for fish biology. Bethesda: Transactions of the American Fisheries Society, pp. 213-272.

THATCHER, V.E., 2006. Amazon fish parasites. 2nd ed. Bulgaria: Pensoft Publishers, Sofia-Moscow. 508 p.

TOMBI J., AKOUMBA, J. F., and BILONG BILONG, C. F., 2014. The monogenean community on the gills of Oreochromis niloticus from Melen fish station in Yaounde, Cameroon. International Journal of Modern Biological Research, vol. 2, pp. 16-23.

TRIPATHI, P., AGRAWAL, N., PANT, R. and AGRAWAL, G.G., 2010. Microhabitat distribution of some monogenoideans, parasitizing the gills of Wallago attu (Bl. and Sch., 1801) and their seasonal variation. Journal of Parasitic Diseases: Official Organ of the Indian Society for Parasitology, vol. 34, no. 1, pp. 24-28. http://dx.doi.org/10.1007/s12639-010-0008-1. PMid:21526029.

TURGUT, E., SHINN, A. and WOOTTEN, R., 2006. Spatial distribution of dactylogyrus (Monogenan) on the gills of the host fish. Turkish Journal of Fisheries and Aquatic Sciences, vol. 6, pp. 93-98

VELISEK, J., LASOW, T., GOMULKA, P., SVOBODOVA, Z., NOVOT, L. and ZIOMEK, E., 2006. Effects of clove oil anaesthesia on european catfish (Silirus glanis L.). Acta Veterinaria, vol. 75, no. 1, pp. 99-106. http://dx.doi.org/10.2754/avb200675010099.

VELISEK, J., SVOBODOVA, Z., PIACKOVA, V., GROCH, L. and NEPEJCHALOVA, L., 2005. Effects of clove oil anaesthesia on common carp (Cyprinus carpio L.). Veterinary Medicine Czech, vol. 50, no. 6, pp. 269-275.

ZHANG, Q., XU, D.H., and KLESIUS, P.H., 2013. Evaluation of an antiparasitic compound extracted from against fish parasite. Veterinary Parasitology, vol. 198, pp. 45-53. http://dx.doi. org/10.1016/j.vetpar.2013.08.019. PMid:24070778. 